\title{
Efikasi Beberapa Isolat Jamur Metarhizium anisopliae Terhadap Hama Uret Lepidiota stigma F. (Coleoptera: Scarabaeidae) di Laboratorium
}

\section{Efficacy of Metarhizium anisopliae Isolates Against White Grub Lepidiota stigma F. (Coleoptera: Scarabaeidae) in The Laboratory}

\author{
Wiwit Wicaksono Jati ${ }^{1)}$, Etik Mar'ati Achadian ${ }^{1)}$ \\ Dendi Juliadi ${ }^{1)}$, dan Lilik Koesmihartono Putra ${ }^{1)}$
}

1) Pusat Penelitian Perkebunan Gula Indonesia, Pasuruan

Alamat korespondensi, Email: jatiwiwit@gmail.com

\begin{abstract}
ABSTRAK
Serangan hama uret Lepidiota stigma F. dapat menyebabkan kehilangan hasil tebu mencapai $30 \%$, dan pada serangan berat dapat menyebabkan gagal panen. Pengendalian hama dengan aplikasi insektisida sintetik secara terus menerus berpotensi menimbulkan dampak negatif terhadap keseimbangan ekosistem antara lain pencemaran lingkungan. Pengendalian secara biologis dengan jamur entomopatogenik merupakan alternatif teknik pengendalian yang dapat dikembangkan. Oleh karena itu tujuan penelitian ini adalah untuk mengetahui kemampuan 5 isolat jamur Metarhizium anisopliae yang diperoleh dari beberapa instansi untuk pengembangan agen hayati hama uret di wilayah Purworejo. Penelitian uji efikasi dilakukan dalam 2 tahap. Uji efikasi tahap 1 dilakukan pada 5 isolat terhadap uret dari Purworejo. Adapun uji efikasi tahap 2 dilakukan pada 2 isolat terpilih dengan penyetaraan kerapatan spora. Hasil penelitian menunjukkan bahwa terdapat 2 isolat yang mampu menyebabkan kematian hama uret yaitu isolat M1 dan M5. Isolat M5 menunjukkan hasil uji efikasi tahap pertama yang lebih tinggi dibandingkan isolat lainnya. Hasil uji efikasi tahap 2 antara isolat jamur M. anisopliae M1 dan M5, keduanya efektif untuk mengendalikan hama uret L. stigma.
\end{abstract}

Kata kunci : Uret, Purworejo, jamur, efikasi

\section{ABSTRACT}

The white grub Lepidiota stigma F. infestation decreases sugarcane yield up to $30 \%$ and heavy infestation causes crop failure. The control method using synthetic insecticides has a potentially negative impact on the ecosystem balance, including environmental pollution. Biological control with entomopathogenic fungus is an alternative control technique that can be developed. Therefore the purpose of this study was to determine the efficacy of 5 isolates of Metarizium anisopliae obtained from several institutions in the development of white grub's biological control agent in Purworejo. The efficacy test was carried out in 2 stages. For the first stage, an efficacy test was conducted on 5 isolates against white grub from Purworejo area. An efficacy test for the second stage was conducted on 2 selected isolates with equalization of spore density. The first stage result showed that there were 2 isolates 
have efficacy in controlling white grub, namely M1 and M5 isolates. M5 isolate had higher efficacy than other fungal isolates. The second-stage efficacy result showed that both of MI and M5 isolates can be used as biological control agent of L. stigma white grub.

Key words: White grub, Purworejo, fungus, efficacy

\section{PENDAHULUAN}

Uret merupakan hama penting di perkebunan tebu khususnya di lahan kering berpasir. Dalam kurun waktu \pm 20 tahun terdapat kecenderungan terjadi peningkatan luas dan intensitas serangan uret di Indonesia. Peningkatan tersebut seiring dengan semakin bergesernya tanaman tebu ke lahan kering. Hasil survei pada tahun 1990 menunjukkan hanya 6 pabrik gula (PG) yang memiliki masalah dengan serangan uret (Suhartawan, 1993).

Berbeda dengan survey sebelumnya, hasil survei yang dilaksanakan pada tahun 2008-2009 diketahui semakin banyak kebun tebu yang terserang uret. Kebun-kebun tersebut tersebar di 11 PG di Jawa Timur (PG Asembagus, PG Semboro, PG Prajekan, PG Jatiroto, PG Ngadirejo, PG Pesantren Baru, PG Mrican, PG Jombang Baru, PG Pagotan, PG Purwodadi and PG Sudono), 4 PG di Jawa Tengah (PG Rendeng, PG Jatibarang, PG Sragi dan PG Gondang Baru) serta 1 PG di DIY (PG Madubaru) dan 1 PG di Jawa Barat (PG Karangsuwung) (Achadian et al., 2012). Spesies yang paling dominan menyerang tebu dan menimbulkan kerusakan parah adalah Lepidiota stigma (Coleoptera: Scarabaeidae) (Suhartawan, 1993; Achadian et al., 2012).

Uret merupakan hama yang sangat merugikan karena aktivitas makannya merusak akar tebu sehingga mengurangi penyerapan air dan hara. Gejala serangan uret akan terlihat jelas ketika musim kering dimana daun tebu menjadi menguning, batang roboh dan tanaman tebu mati sehingga menyebabkan kerusakan yang semakin parah pada tanaman keprasan. Serangan uret dapat menyebabkan penurunan produktivitas tebu dan kualitas gula. Kehilangan hasil akibat serangan uret diperkirakan dapat mencapai $30 \%$ dan dapat menyebabkan gagal panen jika terjadi serangan sangat berat (Samoedi, 1993; Pramono, 2005).

Penggunaan jamur entomopatogenik sebagai bagian dari PHT hama uret telah banyak dilakukan di beberapa negara di dunia. Di Australia, jamur Metarhizium anisopliae digunakan untuk mengendalikan hama uret (Dermolepida arbohirtum). Jamur tersebut juga telah tersedia secara komersial. Hasil percobaan Chelvi et al. (2011), aplikasi Metarhizium anisopliae juga efektif untuk mengendalikan hama uret (Holotrichia serrata) pada tanaman tebu di India. Aplikasi jamur merupakan pengendalian jangka panjang namun lebih ramah lingkungan dibanding penggunaan insektisida (Samson et al., 2001).

Gejala infeksi pada L. stigma yang disebabkan oleh $M$. anisopliae adalah mati dalam keadaan kaku, berwarna putih, dan tidak berbau. Hal tersebut terjadi karena semua jaringan dan cairan dalam tubuh serangga habis diserap oleh jamur, sehingga serangga mati dengan tubuh mengeras seperti mumi. Hifa tumbuh keluar permukaan serangga melalui spirakel, mulut dan membran intersegmen (Kershaw et al., 1999). $M$. anisopliae yang telah tumbuh kemudian berubah menjadi hijau ketika konidia sudah masak. Perubahan warna dari awal ditemukannya L. stigma yang diselimuti jamur berwarna putih hingga berwarna hijau kurang lebih selama 3-4 hari. 
Di Indonesia pemanfaatan jamur Metarhizium telah dilakukan untuk mengendalikan hama kopi, kakao, kelapa, tebu dan lain-lain. Hasil penelitian Harjaka (2006 dan 2010) menyebutkan bahwa jamur M. anisopliae yang diisolasi dari Phyllophaga helleri mampu menyebabkan mortalitas terhadap larva L. stigma instar ketiga. Sementara itu P3GI telah menghasilkan produk jamur $M$. anisopliae yang diisolasi dari larva L. stigma dan terbukti efektif untuk pengendalian L. stigma (Achadian, 2014).

Pengendalian uret yang hanya bertumpu pada aplikasi insektisida umumnya tidak menyelesaikan permasalahan uret di lapang. Bahkan di beberapa lokasi seperti di wilayah Purworejo, hama uret masih menjadi hama utama yang belum dapat dikendalikan dengan baik. Aplikasi insektisida sintetik secara terus menerus berpotensi menimbulkan dampak negatif terhadap keseimbangan ekosistem antara lain pencemaran lingkungan serta resistensi dan resurjensi hama. Untuk mengatasi permasalahan tersebut, pengendalian biologis dengan mikroba yang bersifat entomopatogenik merupakan alternatif teknik pengendalian yang dapat dikembangkan. Tujuan Penelitian ini adalah untuk mengetahui kemampuan 5 isolat Metarizium anisopliae yang diperoleh dari beberapa instansi dalam pengembangan agen hayati di wilayah Purworejo.

\section{METODE}

\section{Waktu dan tempat}

Penelitian ini dilakukan di Laboratorium Proteksi Tanaman Pusat Penelitian Perkebunan Gula Indonesia (P3GI) Pasuruan. Uji efikasi dilakukan mulai bulan JuniAgustus 2016.

\section{Bahan dan Alat}

Bahan yang digunakan yaitu isolat $M$. anisopliae yang berasal dari lembaga berbeda yaitu dari Pasuruan (M1), Jombang (M2), Malang (M3), Bogor (M4), dan Yogyakarta (M5), larva uret L. stigma instar 3, PDA (Potatoes Dextrose Agar) (Difco ${ }^{T M} B D$ Becton), PDB (Potatoes Dextrose Broth), beras jagung, tanah steril, air steril, aluminium foil, kapas, plastic wrap, alkohol $70 \%$, Alat yang digunakan dalam penelitian ini antara lain: cawan petri, jarum ose, tabung reaksi (Pyrex), Laminar Air Flow Cabinet (LAFC) (Bass Aire), autoklaf, pipet 200$1000 \mu 1$ (Socorex), pembakar Bunsen, tabung Erlenmeyer (Iwaki Pyrex), sprayer mini, haemocytometer, sekop kecil, pinset, spatula, mikroskop (Axiostar-zeiss), gelas beker (Pyrex Iwaki Glass), batang pengaduk, kantong plastik (1 dan 0,5 kg), pipa PVC (diameter $3 \mathrm{~cm}$ ), termometer ruangan, ember, vial plastik (cepuk), timbangan analitik (Sartorius laboratory), pengaduk/shaker (Branstead/Thermolyne), $\mathrm{pH}$ meter (Cyberscan $1000 \mathrm{pH})$, kamera serta peralatan potong dan tanam bibit.

\section{Prosedur penelitian}

Penelitian diawali dengan penyiapan serangga uji yaitu larva/uret L. stigma. Larva instar 3 diambil dari areal perkebunan tebu rakyat di Kabupaten Purworejo Jawa Tengah, yang merupakan daerah endemi serangan uret L. stigma. Pengumpulan dilakukan dengan cara menggali lubang di sekitar perakaran tanaman tebu. Uret yang diperoleh kemudian dikumpulkan dalam kotak dan diberi media tanah setempat. Selain itu juga dilakukan pengambilan tanah untuk media pemeliharaan uret.

Uret dari lapang kemudian dipelihara di laboratorium dalam vial plastik (cepuk) ukuran $\varnothing 6 \mathrm{~cm} \times 8 \mathrm{~cm}$ secara invidual menggunakan media tanah dari Purworejo yang sudah disterilkan dan diberi makanan berupa potongan benih tebu (bagal mata 1 yang telah berakar). Pemberian atau penggantian pakan dilakukan setiap tujuh 
hari. Untuk menjaga kelembaban, media tanah diberikan air steril sebanyak $10 \mathrm{ml}$. Pemeliharaan dilakukan selama 2 minggu sebelum dilakukan pengujian untuk memilih serangga uji yang betul-betul sehat.

Isolat jamur M. anisopliae ditumbuhkan pada media PDA (Potato Dextrose Agar) dalam tabung reaksi selama 14 hari. Setiap isolat jamur kemudian diperbanyak pada 150 $\mathrm{ml}$ media PDB (Potato Dextrose Broth) dalam tabung Erlenmeyer dengan $\mathrm{pH}$ 5,1 dan digojok selama 3 hari. Jamur yang sudah tumbuh pada media PDB kemudian diperbanyak pada media alami berupa jagung yang sudah disterilkan dalam autoklaf pada suhu $120^{\circ} \mathrm{C}$, tekanan 1 atm selama 15 menit. Jamur pada media jagung diinkubasikan selama 20 hari untuk kemudian digunakan dalam uji efikasi.

Pada pengujian efikasi isolat jamur $M$. anisopliae, inokulasi jamur dilakukan dengan menggunakan metode tular media seperti yang digunakan oleh Harjaka et al (2011) yaitu dengan cara mencampur biakan jamur pada media jagung dengan tanah sebagai media pemeliharaan larva $L$. stigma dengan konsentrasi $10^{9}$ konidia/gr media jagung. Sebelum inokulasi dilakukan penghitungan kerapatan konidia setiap isolat jamur menggunakan rumus (Gabriel \& Riyatno, 1989):

$$
K=\frac{t \times d \times 10^{6}}{n \times 0,25}
$$

Keterangan: $\mathrm{K}=$ konsentrasi konidia, $\mathrm{t}=$ jumlah total konidia dalam kotak sampel yang diamati, $\mathrm{d}=$ faktor pengenceran, $\mathrm{n}=$ jumlah kotak sampel yang diamati, 0,25= faktor koreksi penggunaan kotak sampel skala kecil dalam Haemcytometer.

Uji efikasi dilakukan dalam 2 tahap. Uji efikasi tahap pertama dilakukan terhadap 5 isolat $M$. anisopliae dan uji efikasi tahap 2 dilakukan terhadap 2 isolat yang terpilih. Pada uji efikasi tahap 2 dilakukan penyetaraan kerapatan spora dari kedua isolat. Percobaan menggunakan Rancangan Acak Lengkap dengan 6 perlakuan, 3 kali ulangan dan setiap unit perlakuan digunakan 10 ekor larva L. stigma. Adapun 6 perlakuan yang diuji adalah: 1) Isolat M1 (P3GI, Pasuruan); 2) Isolat M2 (BBP2TP, Jombang); 3) Isolat M3 (Balittas, Malang); 4) Isolat M4 (PPBBI, Bogor); 5) Isolat M5 (UGM, Yogyakarta); dan 6) kontrol.

\section{Analisis Data}

Data mortalitas uret dianalisis dengan menggunakan uji Anova One Way. Apabila perlakuan dinyatakan berpengaruh, maka dilanjutkan dengan uji Beda Nyata Terkecil (BNT) pada taraf 5\%. Data uji efikasi tahap 2, dari 2 isolat terpilih dibandingkan dengan menggunakan Uji T. Analisis Data menggunakan program Statistix versi 8 .

\section{HASIL DAN PEMBAHASAN}

\section{Morfologi Isolat Jamur Entomopatogen Hama Uret}

Hasil pengamatan morfologi kelima isolat jamur $M$. anisopliae yang digunakan dalam penelitian ini seperti disajikan pada Gambar 1. dan Tabel 1.

Hasil pengamatan makroskopis menunjukkan bahwa pada awal pertumbuhan koloni jamur berwarna putih kemudian setelah beberapa hari berubah warna menjadi hijau. Setiap isolat menunjukkan perbedaan warna dan ketebalan miselium. Isolat yang berasal dari M5 memiliki warna lebih muda dan lebih tebal dibandingkan dengan isolat lainnya. Isolat M1 dan M4 memiliki warna hijau zaitun (agak tua) dan miselium terlihat lebih tipis dibandingkan dengan isolat M5 dan M2. Diameter koloni jamur pada media PDA juga menunjukkan perbedaan satu dengan yang lain. Hal ini menandakan bahwa masing-masing isolat mempunyai kecepatan 
pertumbuhan yang berbeda-beda. Jamur $M$. anisopliae M1 dan M5 menunjukkan pertumbuhan yang lebih cepat dari pada isolat lainnya yaitu dengan diameter mencapai 3,5 $\mathrm{cm}$ dan 2,5 $\mathrm{cm}$ pada hari ke 7 serta $5,06 \mathrm{~cm}$ dan $5,5 \mathrm{~cm}$ pada hari ke 14 .

Hasil pengamatan mikroskopis pada setiap isolat menunjukkan bahwa secara umum konidia berbentuk silindris dan hialin serta membentuk rantai. Ukuran konidia pada setiap isolat menunjukkan adanya perbedaan. Panjang konidia pada isolat $M$. anisopliae M2 adalah 5,84 $\mu \mathrm{m}$ dan isolat M5 3,44 $\mu \mathrm{m}$. Kedua isolat tersebut yang memiliki konidia lebih panjang dari isolat lainnya.

Berdasarkan
hasil pengamatan
makroskopis dan mikrospis tersebut
menunjukan bahwa kelima isolat jamur

tersebut adalah $M$. anisopliae seperti yang digambarkan oleh Barnett dan Hunter (1972) yang menyatakan bahwa $M$. anisopliae memiliki konidia yang bersel satu berwarna hialin, berbentuk silindris. Konidiofor tersusun tegak, berlapis, dan bercabang dipenuhi dengan konidia. Koloni jamur berwarna hijau zaitun, panjang konidiofor mencapai $75 \mu \mathrm{m}$, bertumpuk-tumpuk diselubungi oleh konidia berbentuk apikal berukuran 6-9,5x1,5-3,9 $\mu \mathrm{m}$ dan bercabangcabang. Kelima isolat jamur $M$. anisopliae yang digunakan dalam penelitian menunjukkan adanya perbedaan satu sama lainnya yaitu dalam hal warna koloni, kecepatan pertumbuhan serta ukuran konidia. Oleh karena itu patut diduga bahwa antar isolat tersebut adalah strain yang berbeda.

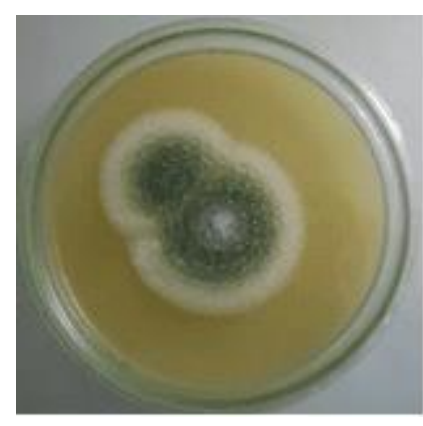

(a)

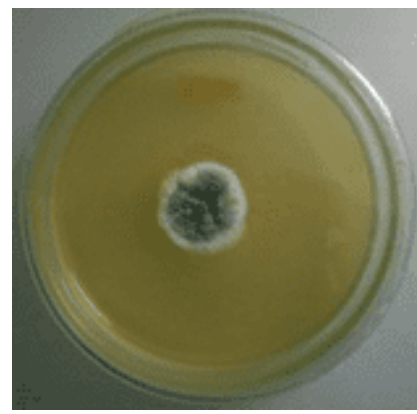

(b)

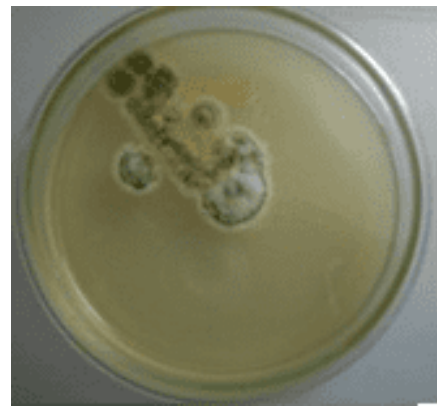

(c)

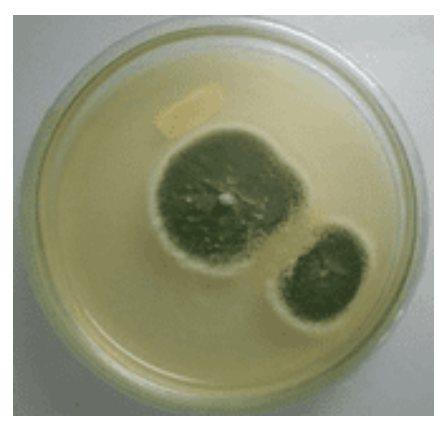

(d)

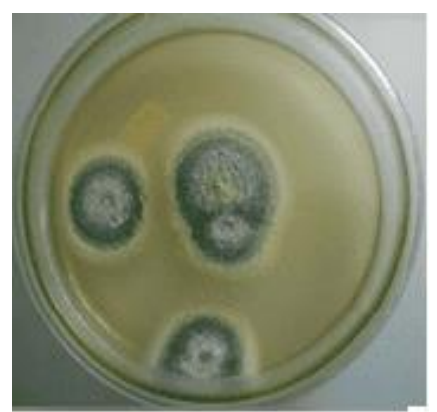

(e)

Gambar 1. Isolat jamur M1 (a), M2 (b), M3 (c), M4 (d), dan M5 (e) pada umur 2 minggu.

Figure 1. Isolates of M1 (a), M2 (b), M3 (c), M4 (d), and M5 (e) at 2 weeks old 
Tabel 1. Morfologi isolat M. anisopliae

Table 1. Morphology of M. anisopliae isolates

\begin{tabular}{|c|c|c|c|c|}
\hline $\begin{array}{l}\text { Kode isolat } \\
\text { Isolate code }\end{array}$ & $\begin{array}{c}\text { Ukuran } \\
\text { konidia } \\
\text { PxL }(\mu \mathrm{m}) \\
\text { Conidia size }\end{array}$ & $\begin{array}{c}\text { Diameter } \\
\text { koloni umur } \\
7 \text { hari }(\mathrm{cm}) \\
\text { Colony } \\
\text { diameter in } \\
7 \text { days }(\mathrm{cm})\end{array}$ & $\begin{array}{c}\text { Diameter } \\
\text { koloni umur } \\
14 \text { hari }(\mathrm{cm}) \\
\text { Colony } \\
\text { diameter in } 14 \\
\text { days }(\mathrm{cm}) \\
\end{array}$ & $\begin{array}{l}\text { Gambar konidia } M . \\
\text { anisopliae } \\
\text { M. anisopliae conidia } \\
\text { picture }\end{array}$ \\
\hline M1 & $2,74 \times 1,43$ & 3,5 & 5,06 & \\
\hline M2 & $5,84 \times 1,31$ & 1,3 & 3,08 & \\
\hline M3 & $2,93 \times 1,64$ & 2,25 & 3,30 & \\
\hline M4 & $2,76 \times 1,64$ & 1,9 & 2,20 & \\
\hline M5 & $3,44 \times 1,29$ & 2,5 & 5,50 & \\
\hline
\end{tabular}

\section{Pengujian Efikasi Tahap 1}

Hasil pengamatan kerapatan konidia jamur yang diaplikasikan disajikan pada Tabel 2. Adapun persen mortalitas uret tersaji pada Tabel 3. Isolat jamur M3 memiliki nilai kerapatan konidia yang tertinggi dibandingkan isolat jamur yang lain yaitu mencapai 5,07.109. Isolat M1, M2, dan M4 memiliki nilai kerapatan yang hampir sama yaitu berkisar 2,16-2,7 .109 . Sementara itu jamur M5 memiliki kerapatan konidia yang lebih rendah dari jamur M3 
tetapi lebih tinggi dari yang lainnya yaitu $4,7.10^{9}$.

Tabel 2. Kerapatan konidia 5 isolat jamur M. anisopliae yang diaplikasikan pada uji efikasi

Table 2. Conidia density of $5 \mathrm{M}$. anisopliae isolates applied on the efficacy test

\begin{tabular}{|c|c|c|}
\hline $\begin{array}{l}\text { No. } \\
\text { No. }\end{array}$ & $\begin{array}{c}\text { Isolat } \\
\text { Isolates }\end{array}$ & $\begin{array}{c}\text { Kerapatan } \\
\text { konidia Jamur } \\
\text { Fungus conidia } \\
\text { density }\end{array}$ \\
\hline 1 & M1 (Pasuruan) & $2,40 \times 10^{9}$ \\
\hline 2 & M2 (Jombang) & $2,16 \times 10^{9}$ \\
\hline 3 & M3 (Malang) & $5,07 \times 10^{9}$ \\
\hline 4 & M4 (Bogor) & $2,70 \times 10^{9}$ \\
\hline 5 & M5 (Yogyakarta) & $4,70 \times 10^{9}$ \\
\hline
\end{tabular}

Tabel 3 menunjukkan bahwa dari 5 isolat jamur yang diuji yang dapat menyebabkan kematian uret hingga pengamatan pada minggu ke- 6 hanya ada dua isolat yaitu M1 dan M5. Namun demikian tingkat mortalitas uret relatif rendah, yaitu berkisar 10-23\%. Secara statistik kedua perlakuan berbeda nyata dengan kontrol. Tingkat mortalitas M5 lebih tinggi dan berbeda nyata bila dibandingkan dengan M1. Sementara itu tiga isolat lainnya tidak menyebabkan kematian pada uret.

Apabila dikaitkan antara nilai kerapatan konidia dengan tingkat mortalitas uret tampak bahwa isolat M3 memiliki nilai kerapatan yang tinggi tetapi tidak memberikan kematian pada uret. Sementara itu isolat M5 dengan nilai kerapatan hampir sama dengan M3 berpengaruh dalam mematikan uret. Isolat M1, M2 dan M4 memiliki nilai kerapatan yang hampir sama tetapi yang mampu mematikan uret hanya isolat M1. Nilai kerapatan konidia ternyata tidak berhubungan dengan tingkat virulensi masing-masing isolat terhadap serangga uji.

Hasil penelitian menunjukkan masingmasing isolat memiliki tingkat virulensi yang berbeda. Geden et al. (1995) menyatakan bahwa isolat yang lebih virulen memiliki pertumbuhan yang lebih cepat dan miselianya lebih padat. Sebaliknya isolat yang avirulen/virulensi rendah tumbuh lebih lambat dan sering terkontaminasi bakteri. Isolat M1 dan M5 memiliki tingkat virulensi yang lebih baik dibandingkan dengan 3 isolat lainnya karena kedua isolat tersebut memiliki pertumbuhan yang lebih cepat yang ditunjukkan dengan diameter koloni yang lebih besar bila dibandingkan dengan ke-3 isolat lainnya (Tabel 1). Pada isolat M3 selain pertumbuhannya lambat juga dalam proses pemurniannya sering kali mengalami kontaminasi.

Tabel 3. Persentase mortalitas uret pada uji efikasi tahap pertama 5 isolat jamur M. anisopliae.

Table 3. Percentage of white grub mortality in the first stage efficacy test of 5 fungal isolates of M. anisopliae.

\begin{tabular}{|c|c|c|}
\hline $\begin{array}{l}\text { No. } \\
\text { No. }\end{array}$ & $\begin{array}{c}\text { Perlakuan isolat } \\
\text { Treatment }\end{array}$ & $\begin{array}{c}\text { Persentase } \\
\text { mortalitas uret } \\
\text { Percentage white } \\
\text { grub mortality }\end{array}$ \\
\hline 1 & M0 (Kontrol) & $0 \mathrm{c}$ \\
\hline 2 & M1 (Pasuruan) & $10 \mathrm{~b}$ \\
\hline 3 & M2 (Jombang) & $0 \mathrm{c}$ \\
\hline 4 & M3 (Malang) & $0 \mathrm{c}$ \\
\hline 5 & M4 (Bogor) & $0 \mathrm{c}$ \\
\hline 6 & M5 (Yogyakarta) & 23,33 a \\
\hline & $\begin{array}{l}\text { BNT } 5 \% \\
L S D 5 \%\end{array}$ & $\begin{array}{l}4,19 \\
4,19\end{array}$ \\
\hline
\end{tabular}

Keterangan: Angka yang diikuti oleh huruf yang sama pada kolom yang sama tidak berbeda nyata pada uji BNT 5\%

Note: Number followed by different letters indicated significant differences $(\alpha=0,05 \%)$ 
Isolat M1 dan M5 merupakan isolat jamur M. anisopliae yang telah dilaporkan mampu mengendalikan Lepidiota stigma di lapang (Achadian, 2014 dan Harjaka et al., 2011). Isolat M2 dan M3 juga diinformasikan oleh pemilik isolat dapat menginfeksi L. stigma. Tampaknya dalam penelitian ini isolat M2 dan M3 menunjukkan tingkat patogenisitas atau virulensi yang lebih rendah dibanding isolat M1 dan M5 sehingga 6 minggu setelah aplikasi tidak ada uret yang mati. Sementara itu untuk isolat M4, berdasarkan informasi dari pemilik produk, isolat tersebut belum pernah diujicobakan untuk L. stigma.

Jamur entomopatogen mempunyai kespesifikan inang. Jamur akan menunjukkan virulensi yang tinggi apabila diaplikasikan pada inang aslinya atau spesies serangga yang mempunyai hubungan dekat dengan serangga inangnya (Feng et al., 1994). Asal isolat juga mempengaruhi keragaman virulensi jamur terhadap serangga inang karena berhubungan dengan jenis atau ras atau strain jamur (Bedjo et al., 2000).
Dari hasil uji efikasi diketahui hanya ada 2 isolat yang dapat membunuh uret $L$. stigma yaitu M1 dan M5. Gejala infeksi $M$. anisopliae ditunjukan pada Gambar 2. Kedua isolat tersebut menunjukkan tingkat mortalitas yang berbeda nyata. Perbedaan tingkat mortalitas uret pada perlakuan isolat M1 dan M5 kemungkinkan disebabkan perbedaan kerapatan konidia yang diaplikasikan. Dari Tabel 2 terlihat kerapatan konidia isolat M5 yang diaplikasi adalah $4,7 \times 10^{9}$ yaitu 2 kali lipat dari nilai kerapatan konidia isolat M1 yang sebesar 2,4 x $10^{9}$. Prayogo et al. (2005) menyatakan bahwa kerapatan konidia yang diaplikasikan pada serangga target akan mempengaruhi efektivitas jamur $M$. anisopliae. Semakin tinggi kerapatan konidia semakin tinggi pula mortalitas pada serangga. Oleh karena itu untuk mengetahui isolat mana yang lebih efektif maka dilakukan uji lanjutan untuk membandingkan efikasi antara isolat M1 dan M5 pada tingkat kerapatan konidia yang sama yaitu $\pm 4 \times 10^{9}$.

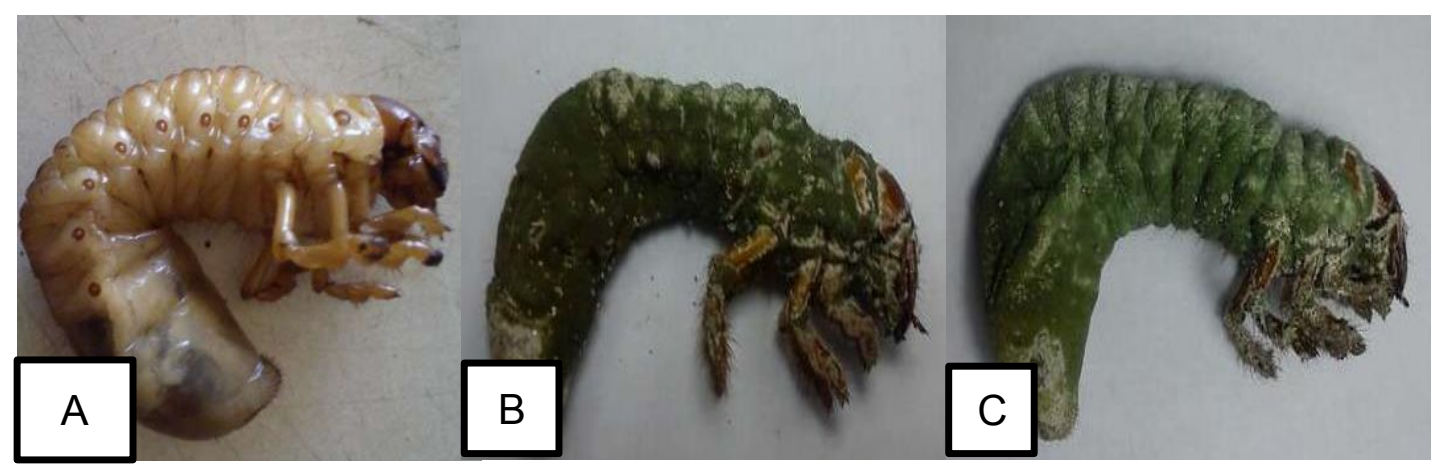

Gambar 2. Gejala larva L. stigma yang terinfeksi M. anisopliae, A). larva sehat, B). larva yang terinfeksi jamur M. anisopliae asal Pasuruan 9 hari setelah aplikasi, C). larva yang terinfeksi jamur $M$. anisopliae asal Yogyakarta 9 hari setelah aplikasi

Figure 2. Symptoms of M. anisopliae infection on larvae of L. stigma, A) healthy larvae, $B$ ) larvae of L. stigma at 9 days after infection of $M$. anisopliae from Pasuruan, C) larvae of L. stigma at 9 days after infection of $M$. anisopliae from Yogyakarta. 


\section{Pengujian Efikasi Tahap 2}

Hasil pengamatan menunjukkan bahwa tingkat mortalitas uret pada perlakuan isolat M1 mencapai $30 \%$ dan isolat M5 mencapai $20 \%$. Dengan aplikasi jamur pada tingkat kerapatan jamur yang sama $\left( \pm 4 \times 10^{9}\right)$, mortalitas M1 lebih tinggi dibandingkan M5 walaupun hasil uji $\mathrm{T}$ antara M1 dan M5 tidak berbeda nyata. Dalam uji banding ini, isolat M1 menunjukan mortalitas uret yang lebih tinggi sejak minggu pertama hingga minggu ke-4 (Gambar 3).

Dari keseluruhan uji efikasi tampak bahwa tingkat mortalitas uret di laboratorium tergolong rendah. Rendahnya persentase mortalitas tersebut diduga disebabkan kondisi lingkungan laboratorium yang cukup panas dengan kelembaban yang rendah sehingga kurang mendukung pertumbuhan jamur. Rata-rata suhu ruangan selama pengamatan adalah $30,2^{0} \mathrm{C}$ dengan kelembaban rata-rata 66,6\%. Menurut Prayogo (2005) suhu optimum pertumbuhan jamur adalah $22-27^{\circ}$ C dan suhu optimum pada waktu infeksi berkisar antara $23-25^{\circ} \mathrm{C}$. Sementara itu menurut Bidochka et al., (2000) kelembaban optimum pertumbuhan jamur adalah di atas 90\%. Virulensi jamur akan semakin menurun jika kelembaban udara juga menurun. Pada kelembaban udara kurang dari $86 \%$, virulensi jamur akan terus menurun.

\section{KESIMPULAN}

Kemampuan isolat Metarizium anisopliase berbeda-beda tergantung pada tingkat virulensi masing masing. Spesifitas isolat dengan asal inang berpengaruh terhadap kemampuan jamur Metarizium anisopliae. Isolat M5 memiliki hasil uji efikasi tahap pertama yang lebih tinggi dibandingkan isolat lainnya. Pada penyetaraan nilai kerapatan spora menunjukkan isolat M1 memiliki nilai mortalitas yang lebih tinggi dibanding isolat M5 meskipun tidak berbeda nyata. Ini berarti kedua isolat M1 dan M5 memiliki potensi sebagai agen pengendali hayati $L$. stigma pada tebu.

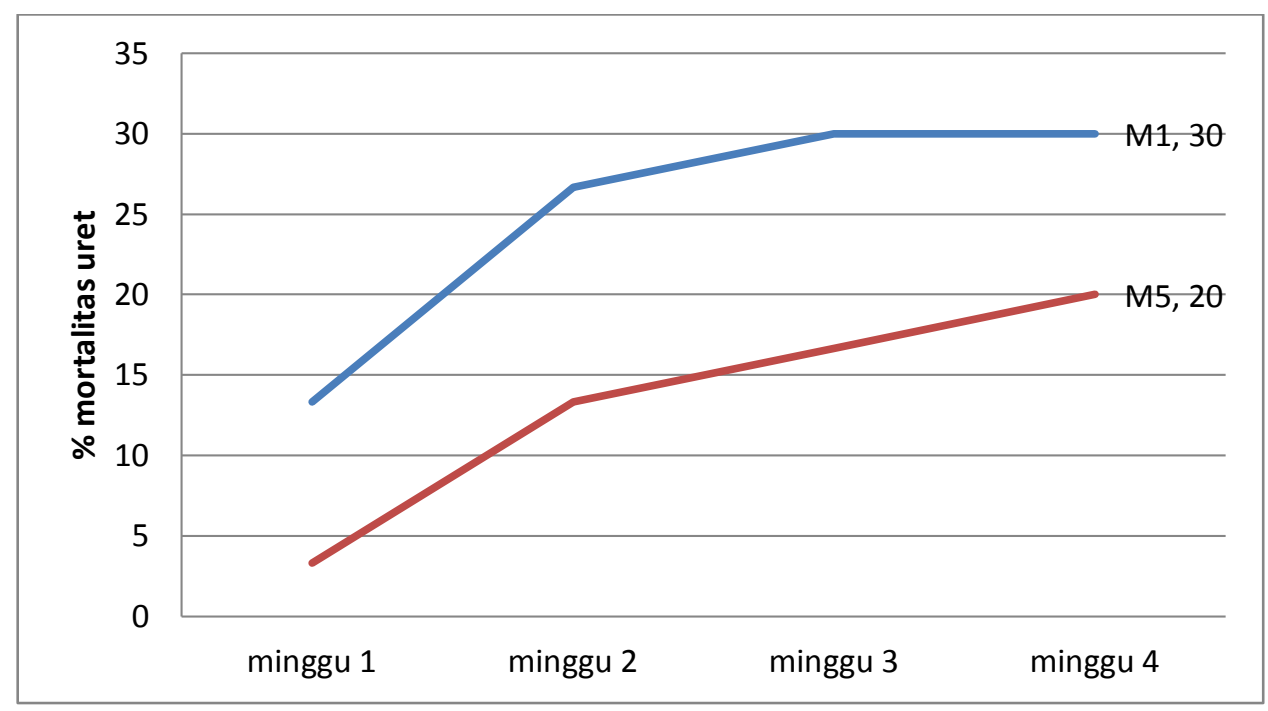

Gambar 3. Perkembangan mortalitas uret pada uji banding isolat M1 dan M5

Figure 3. The development of grub's mortality in the comparative test of isolates M1 and M5 


\section{UCAPAN TERIMA KASIH}

Penulis mengucapkan terimakasih kepada Badan Litbang Pertanian, Kementerian Pertanian selaku penyandang dana penelitian. Ucapan terimakasih juga disampaikan kepada Ir. I Gusti Agung Ayu Indrayani, MP (Balittas), peneliti UGM, BBP2TP dan PPBBI untuk bantuan isolat jamur, Direktur, staf tanaman, petani, petugas lapang PT PG Madu Baru dan Herwan Cahyono Adi, SP. (P3GI) serta Istiqomah, SP. (Mahasiswi UB) atas bantuan yang diberikan terhadap pelaksanaan penelitian ini.

\section{DAFTAR PUSTAKA}

Achadian, E.M., Kristini, A., Putra L. K. and Dian Pratiwi, T. 2012. Hama-hama pertanaman tebu di Jawa: Sebaran, Intensitas Serangan dan Keberadaan Musuh Alami Hama. MPG 48 (2): 73 83

Achadian, E.M. 2014. Pengendalian Terpadu Hama Terpadu Uret di Wilayah PTPN X. Kerjasama P3GI dengan PTPN X. Laporan Kerjasama. $19 \mathrm{hlm}$ (tidak dipublikasikan).

Barnett H.L. and Hunter B.B. 1972. Illustrated Genera of Imperfect Fungi. Third Edition. Burgess. Publishing Company. Minneapolis, Minnesota. 241 p.

Bedjo, Arifin, M., Rahayu, M. \& Sumartini. 2000. Pemanfaatan Nuclear Polyhedrosis Virus, Bacillus thuringiensis dan Metarhizium anisopliae sebagai Biopestisida untuk Pengendalian Hama Kedelai. Laporan Hasil Penelitian The Participatory Development of Agriculture Technology Project (PAATP). Balitkabi. 32 p.

Bidochka, M.J., Kamp, A.M. \& Decroos, J.N.A. 2000. Insect pathogenic fungi: from genes to populations. Fungal Pathol, 42:171-193.

Chelvi, C.T., W. R. Thilagaraj and R. Nalini. 2011. Field efficacy of formulations of microbial insecticide Metarhizium anisopliae (Hyphocreales: Clavicipitaceae) for the control of sugarcane white grub Holotrichia serrata F (Coleoptera :Scarabidae) J. Biopest, 4 (2): 186-189

Feng, M.G., Poprawski, T.J. \& Khachatourians, G.G. 1994. Formulation and application of the entomopathogenic fungus Beauveria bassiana for insect control. J. Biocontrol Science and Technology, 4:3-34.

Gabriel, B.P. \& Riyatno. 1989. Metarhizium anisopliae (Metsch.) Sor: Taksonomi, Patologi, Produksi, dan Aplikasinya. Jakarta: Proyek Pengembangan Perlindungan Tanaman Perkebunan Departemen Pertanian. 25 p.

Geden, C J., A, Rutz D., C, Steinkraus, D. 1995. Virulence of different isolats and formulations of Beauveria bassiana for house flies and the parasitoid Muscidifurax raptor. Bio Control, 5:615-621.

Harjaka, T. 2006. Isolasi jamur Metarhizium anisopliae pada hama uret perusak akar padi gogo. Prosiding Seminar Hasil Penelitian Pertanian. Fakultas Pertanian UGM Hal : 200-205.

Harjaka, T. 2010. Susceptibility of Lepidiota stigma to Metarhizium anisopliae. Papper presented on the International Seminar of Food Safety and Food Security. Dec, 1-2. 2010, Yogyakarta.

Harjaka, T. Martono, E., Witjaksono, Sumarminto, B.H. 2011. Potensi jamur Metharizhium anisopliae untuk pengendalian uret perusak akar tebu. Pros. Seminar Nasional Pesnab IV. Jakarta 15 Oktober 2011. Hal : 91-102. 
Kershaw, M.J., Moorhouse, E.R., Bateman, R., Reynolds, S.E., Charnley, A.K. 1999. The role of destruxin in the pathogenecity of Metarhizium anisopliae for three species of insect. Journal of Invertebrate Pathology, 74:213-223.

Pramono, D. 2005. Seri pengelolaan hama tebu secara terpadu. Dioma. Malang. hal. $79-145$

Prayogo, Y., Tengkano, W. \& Marwoto. 2005. Prospek cendawan entomopatogen Metarhizium anisopliae untuk mengendalikan ulat grayak Spodoptera litura pada kedelai. J. Litbang Pertanian, 24(1):19-23..
Samoedi, D. 1993. Hama-hama Penting Pertanaman Tebu di Indonesia. Pusat Penelitian Perkebunan Gula Indonesia. $36 \mathrm{hlm}$.

Samson, P, L. Robertson, P. Bakker, R. Cocco, A. Horsfield, D. Logan, C. Kettle, W. Harris, P. Allsopp, N. McGill, R. Milner and G. Bullard. 2001. Development of Metarhiziumbased biopesticides for use against sugarcane whitegrubs in Australia. Proc. Int. Soc. Sugar Cane Technol. 24, 354-360

Suhartawan. 1993. Penyebaran Hama-Hama Tebu Penting di Indonesia Pada Saat Ini. Berita P3GI (6) : 58-64. 